\title{
Synthesis, Identification, and Infrared Spectroscopy Study of the Influence of Reaction Parameters Variations on $\mathrm{Cu}\left(\mathrm{C}_{4} \mathrm{O}_{4}\right) \cdot 2 \mathrm{H}_{2} \mathrm{O}$ Synthesis
}

\section{LOUIZA ZENKHRI ${ }^{1 *}$, SALAH ZENKHRI ${ }^{2}$, AHMED BOUTARFAIA ${ }^{3}$, MANAL BASSA ${ }^{1}$, AZIZA SEDRATI ${ }^{1}$ and KHALIDA BENOUNA ${ }^{1}$}

'University Kasdi Merbah Ouargla, Chemistry Department, Faculty of Mathematics and Matter Sciences,

BP 511 Route Ghardaia, Ouargla-30 000, Algeria.

${ }^{2}$ Eecosystem Protection in Arid and Semi-Arid laboratory, Kasdi Merbah University, BP 511, Ouargla -30000, Algeria.

${ }^{3}$ University Mohammed Khider Biskra, Science of Matter Department, Faculty of Exact Sciences and

Sciences of Nature and life, BP 145 RP, Biskra-00700, Algeria.

${ }^{*}$ Corresponding author E-mail: louizazenkhri@yahoo.fr

http://dx.doi.org/10.13005/ojc/350248

(Received: December 03, 2018; Accepted: March 30, 2019)

\section{ABSTRACT}

In this paper, we report synthesis, identification and study of different spectral measurements for $\mathrm{Cu}\left(\mathrm{C}_{4} \mathrm{O}_{4}\right) \cdot 2 \mathrm{H}_{2} \mathrm{O}$ complex in order to valorize effect of experimental conditions on resulting product nature. The structure was identified from a powder X-rays diffraction. This complex was prepared for the first by Christian Rubel and Armin Weiss (1986). Comparative study for variation of different reaction parameters effect was interpreted by infrared spectrum observation for each product. In conclusion, we have put in evidence contribution effect of variation in temperature, $\mathrm{pH}$, concentration, solvent, time of reaction on nature modification of the resulting product.

Keywords: X-rays diffraction, IR spectroscopie, Cupper squarate, Hybrid material, Reaction parameter.

\section{INTRODUCTION}

Several transition metal squarate tetrahydrate salts, $\mathrm{M}\left(\mathrm{C}_{4} \mathrm{O}_{4}\right) \cdot 2 \mathrm{H}_{2} \mathrm{O}$ with divalent metal ions are known. Their structures consist of one dimensional metal squarate chains interlinked by hydrogen bonding ${ }^{1}$. Contrary to earlier expectations, based on similar compounds formed with the oxocarbon ligand. The descriptive study of the crystalline structure of the compound $\mathrm{Cu}\left(\mathrm{C}_{4} \mathrm{O}_{4}\right) \cdot 2 \mathrm{H}_{2} \mathrm{O}$ was carried out using the Mercry 3.8 program, based on the results of $\mathrm{X}$-ray diffraction obtained in 1986 by the study of Christian Robel $^{2}$ on the base of the crystalline data file (cif). The asymmetric unit consists of a $\mathrm{Cu}$ copper atom, 4 carbon atoms, 6 oxygen atoms and 4 hydrogen atoms. The structure is three-dimensional. Structural metal units $\mathrm{SBU}\left(\mathrm{CuO}_{6}\right)$ bound to squarate anions formed by infinite layers parallel to the ab plane.

This is an Open Access article licensed under a Creative Commons license: Attribution 4.0 International (CC- BY). Published by Oriental Scientific Publishing Company @ 2018

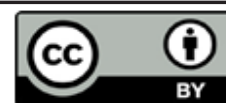




\section{MATERIALS AND METHODS}

All chemicals used were analytical reagents and commercially purchased. IR spectra were obtained with FTIR-8300 CH-HMADZU spectrometer using $\mathrm{KBr}$ pellets in the $4000-400 \mathrm{~cm}$. Elemental analysis for $\mathrm{Cu}, \mathrm{C}$, and $\mathrm{O}$ were performed using a MEB-EDX Quanta TM microanalyser. Diffraction powder experiments were performed at room temperature on a D8 Advence X-ray spectrometer. The sample for measurement was prepared by depositing the dried powder on a PMMA sample holder. The structure was identified using X'Pert HighScore Plus program. The crystal lattice search was carried out with the Dicvol 06 program $^{3,4}$. The program used for powder pattern simulation and molecular graphics is a mercury program. The crystallographic data file (cif) number used is 1152266 .

\section{Synthesis of $\mathrm{Cu}\left(\mathrm{C}_{4} \mathrm{O}_{4}\right) \cdot 2 \mathrm{H}_{2} \mathrm{O}$}

A solution of squarique acid dihydrate $(0,05702 \mathrm{~g})$ in water $(15 \mathrm{ml})$ was added dropwise with stirring at $50^{\circ} \mathrm{C}$ to a solution of $\mathrm{Cu}\left(\mathrm{NO}_{3}\right) 3 . \mathrm{H}_{2} \mathrm{O}$ $(0.2416 \mathrm{~g})$ in distilled water $(15 \mathrm{ml})$. The solution immediately became yellow suspension and was stirred for $4 \mathrm{~h}$ at room temperature. Then green clear solution $(\mathrm{pH}=0,87)$ is formed and was stirred for a day and then cooled to room temperature. Green powder that formed was filtered and washed with water and dried in air (Figure 1(a))

\section{RESULTATS ET DISCUSSION}

\section{Elementary analysis}

Scanning optical microscope analysis results show that the sample consists of three basic elements: carbon (30.69\%), oxygen $43.08 \%$, copper $(26.23 \%)$, with apparent morphology as very small crystallite (Figure 1 (b)).

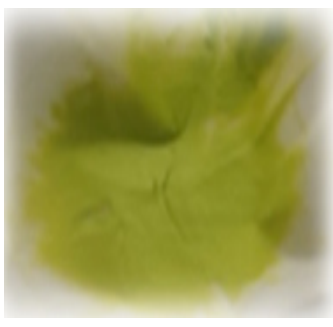

(a)

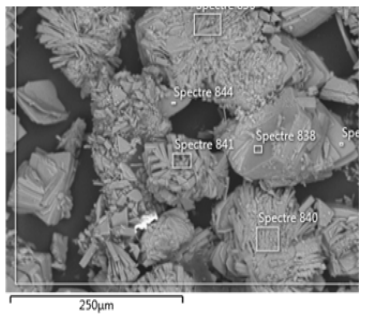

(b)
Fig. 1. (a) Geen product resulting of synthesis, (b) Product morphology

\section{X-Ray diffraction (XRD)}

The chemical formula of title compound was determined using $\mathrm{X}$-ray powder diffraction technique. Fig. 2 shows the curve recorded by the D8 Advance Difractometer in the examined angular range, which is usually the sample fingerprint. XRD experimental data of the synthesized product agree with simulated diffractogram with mercury 3.8 software for $\mathrm{Cu}\left(\mathrm{C}_{4} \mathrm{O}_{4}\right) \cdot 2 \mathrm{H}_{2} \mathrm{O}$ complex (Rubel and Weiss1986) ${ }^{2}$. A parts of experimental powder diffraction pattern of $\mathrm{Cu}\left(\mathrm{C}_{4} \mathrm{O}_{4}\right) \cdot 2 \mathrm{H}_{2} \mathrm{O}$ (red) and powder pattern calculated from the atomic coordinates of cupper related compound (blue) are also presented with part of Rietveld plot which highlights the fabrication of the molecule of the same formula $\mathrm{Cu}\left(\mathrm{C}_{4} \mathrm{O}_{4}\right) \cdot 2 \mathrm{H}_{2} \mathrm{O}$ (Figure 2).

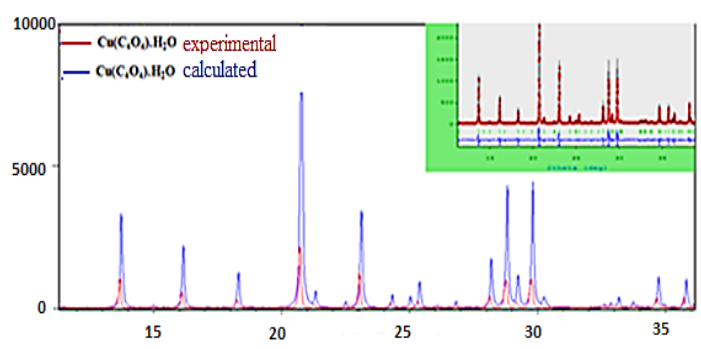

Fig. 2. Parts of the experimental powder diffraction pattern of $\mathrm{Cu}\left(\mathrm{C}_{4} \mathrm{O}_{4}\right) \cdot 2 \mathrm{H}_{2} \mathrm{O}$ (red) and the powder pattern calculated from the atomic coordinates of the europium related compound black with part of Rietveld plot

Indexing with DIVCOL 06 program leads in a monoclinic unit cell with parameters noted in table 1 and figures of merit $\mathrm{M}(21)=86.0, \mathrm{~F}(21)=129.9$ $(0.0027,95)$ revealing crystallization quality. These results also show that the structure of this compound will be modeled in a space group different from that found in the work of Christian Rubel because of different arrangement of Cell dimensions in the unit cell, as shown in the Table 2.

\section{Cristal structure}

The compound described previously in the literature ${ }^{2}$. The central $\mathrm{Cu}$ atom has octahedral coordination geometry composed of six oxygen atoms, tree from squarate ligands and tree from water molecule (Figure 3).

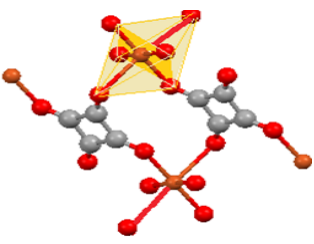

Fig. 3. The molecular structure of the title compound, showing octahedral coordination geometry 
Table 1: Indexing data of X-ray diffraction pattern for $\mathrm{Cu}\left(\mathrm{C}_{4} \mathrm{O}_{4}\right) \cdot 2 \mathrm{H}_{2} \mathrm{O}$ synthesized

\begin{tabular}{|c|c|c|c|c|c|c|c|c|}
\hline \multicolumn{9}{|c|}{$\begin{array}{l}\text { Monoclinic } \\
\text { Crystal systema= } \\
\text { Cell dimensions }\end{array}$} \\
\hline \multirow{2}{*}{$\frac{\mathrm{H}}{1}$} & \multirow[t]{2}{*}{$\mathrm{K}$} & \multirow{2}{*}{$\frac{\mathrm{L}}{0}$} & \multirow{2}{*}{$\frac{\text { DOBS }}{6.48374}$} & \multirow{2}{*}{$\frac{\mathrm{DCAL}}{6.48444}$} & \multicolumn{2}{|c|}{ DOBS-DCAL2TH.OBS } & \multirow{2}{*}{$\frac{2 \mathrm{TH} . \mathrm{CAL}}{13.645}$} & \multirow{2}{*}{$\frac{\text { DIF.2TH. }}{0.001}$} \\
\hline & & & & & 0.00070 & 13.646 & & \\
\hline 0 & 1 & 1 & 5.50871 & 5.50848 & 0.00023 & 16.076 & 16.077 & $0.001-$ \\
\hline 1 & 1 & -1 & 4.86255 & 4.86152 & 0.00103 & 18.23 & 18.234 & $0.004-$ \\
\hline 0 & 2 & 1 & 4.18191 & 4.29037 & 0.00018- & 20.687 & 20.686 & 0.001 \\
\hline 1 & 1 & 1 & 3.96459 & 4.18232 & $0.00041-$ & 21.229 & 21.227 & 0.002 \\
\hline 1 & 2 & -1 & 3.86213 & 3.96252 & 0.00207 & 22.407 & 22.419 & $0.012-$ \\
\hline 2 & 0 & 0 & 3.67171 & 3.86296 & 0.00084 & 23.01 & 23.005 & 0.005 \\
\hline 2 & 1 & 0 & 3.56892 & 3.67256 & $0.00085-$ & 24.22 & 24.215 & 0.006 \\
\hline 1 & 2 & 1 & 3.51803 & 3.56793 & 0.001 & 24.929 & 24.936 & $0.007-$ \\
\hline 1 & 3 & 0 & 3.51803 & 3.51843 & -0.0004 & 25.296 & 25.293 & 0.003 \\
\hline 1 & 3 & -1 & 3.17284 & 3.51843 & 0.00001 & 28.101 & 28.101 & 0 \\
\hline 0 & 0 & 2 & 3.10399 & 3.17282 & 0.00001 & 28.101 & 28.101 & 0 \\
\hline 2 & 2 & -1 & 3.06132 & 0.06204 & 0.00072 & 29.147 & 29.14 & 0.007 \\
\hline 0 & 1 & 2 & 3.00269 & 3.00283 & 0.00014 & 29.729 & 29.728 & 0.001 \\
\hline 0 & 4 & 0 & 2.96287 & 2.96311 & 0.00024- & 30.138 & 30.136 & 0.003 \\
\hline 1 & 3 & 1 & I & 2.95903 & 0.00384 & l & 30.178 & $0.040-$ \\
\hline 1 & 4 & -1 & 2.58815 & 2.58832 & -0.00017 & 34.63 & 34.628 & 0.002 \\
\hline 3 & 1 & 0 & 2.51498 & 2.51441 & 0.00056 & 35.671 & 35.679 & $0.008-$ \\
\hline 1 & 2 & 2 & 2.46897 & 2.46941 & -0.00044 & 36.359 & 36.352 & 0.007 \\
\hline 1 & 4 & 1 & l & 2.46822 & 0.00074 & l & 36.37 & $0.011-$ \\
\hline 3 & 2 & 0 & 2.35015 & 2.35958 & 0.00006 & 38.107 & 38.108 & -0.001 \\
\hline 2 & 4 & 0 & 2.35015 & 2.34957 & 0.00059 & 38.266 & 38.276 & -0.01 \\
\hline 1 & 5 & 0 & 2.26487 & 2.26508 & -0.00021 & 39.767 & 39.763 & 0.004 \\
\hline \multicolumn{4}{|c|}{ NUMBER OF LINE } & \multicolumn{5}{|c|}{$Q>=0.19211 .10-04$} \\
\hline \multicolumn{3}{|c|}{ LINES INPUT } & $=21$ & \multicolumn{5}{|c|}{ FIGURES OF MERIT } \\
\hline \multicolumn{3}{|c|}{ LINES INDEXED } & $=21$ & \multicolumn{5}{|c|}{ 1.- $M(21)=86.0$} \\
\hline \multicolumn{3}{|c|}{ LINES CALCULATED } & $=59$ & \multicolumn{5}{|c|}{ 2. $F(21)=129.9(0.0027,59)$} \\
\hline
\end{tabular}

Table 2: Cell parameters of $\mathrm{Cu}\left(\mathrm{C}_{4} \mathrm{O}_{4}\right) \cdot 2 \mathrm{H}_{2} \mathrm{O}$

\begin{tabular}{lcccccccc}
\hline Experimental result & & 6.2971 & 11.8307 & 7.8321 & 90 & 100.247 & 90 & 574.18 In this work \\
Calculated result & $\mathrm{P}_{2} / \mathrm{C}$ & 7.818 & 11.816 & 6.295 & 90 & 100.3 & 90 & 572.45 (Rubel and Weiss1986) \\
\hline
\end{tabular}

\section{Infrared spectroscopy analysis}

Once the product crystalline structure is known, and for purpose of optimize reactions model for this material preparation we propose the registration of an infrared spectrum template for this compound and then carried out similar chemical reactions with modification of parameters reaction for every time. The study of reaction parameters influence on products nature was described by interpretation of the recorded infrared spectra.

Figure 4 shows the infrared spectrum recorded for $\mathrm{Cu}\left(\mathrm{C}_{4} \mathrm{O}_{4}\right) \cdot 2 \mathrm{H}_{2} \mathrm{O}$ in the spectral range (4000-400) $\mathrm{cm}^{-1}$ frequency range at room temperature.

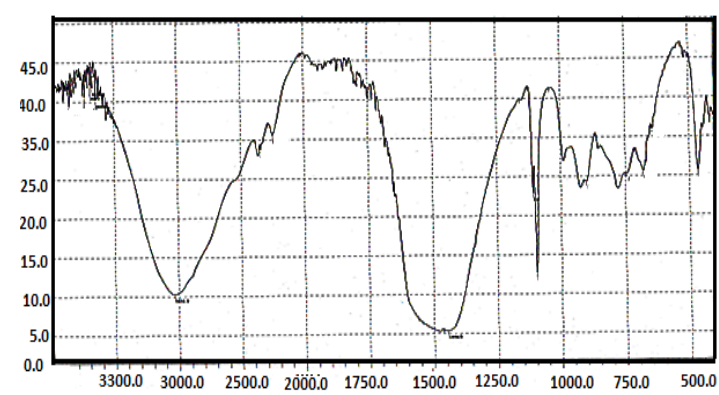

Fig. 4. FT-Infrared of $\mathrm{Cu}\left(\mathrm{C}_{4} \mathrm{O}_{4}\right) \cdot 2 \mathrm{H}_{2} \mathrm{O}$ between 4000 and $400 \mathrm{~cm}^{-1}$

The IR spectra exhibit the characteristic bands of both squarate and bands of cupper-oxygen. The spectrum shows that most of the bands observed are broad and dense, especially those corresponding 
to the $\mathrm{OH}$ group, followed by intermediate bands, weak, less dense, and representing the other functional groups in the sample. In the Table 3 are listed the values of the waves of the functional groups in $\mathrm{cm}^{-1}$ with the type of vibration.

Table 3 : Characteristic infrared bands of $\mathrm{Cu}\left(\mathrm{C}_{4} \mathrm{O}_{4}\right) \cdot 2 \mathrm{H}_{2} \mathrm{O}$ and their interpretations

\begin{tabular}{|c|c|c|}
\hline \multicolumn{2}{|c|}{ Band in this work $\left(\mathrm{cm}^{-1}\right)$} & in $\left(\mathrm{cm}^{-1}\right)$ Band \\
\hline$v C-C$ & 1095.5 & (Reinprecht and al, 1980) \\
\hline vC-O & 1446.5 & (Bellamy, 1975) \\
\hline$v \mathrm{C}=\mathrm{O}, v \mathrm{C}=\mathrm{C}$ & 1750 & 1822(Baglin and Rose, 1970) \\
\hline$v \mathrm{O}-\mathrm{H}$ & 3031.9 & (Erer et al, 2010) \\
\hline vCu-O & $466.7-644.2$ & ( Doreswamy et al.,2005) \\
\hline
\end{tabular}

The spectrum shows a weak and less dense peak at $1095.5 \mathrm{~cm}^{-1}$ corresponds to $\mathrm{C}-\mathrm{C}$ bond vibrations in squaric acid, while the relatively broad and dense band $1446.5 \mathrm{~cm}^{-1}$ represents CO bond vibration in the same anion. The band 3031.7 $\mathrm{cm}^{-1}$ represents the vibration of the $\mathrm{OH}$ bond of the water molecules. Metal-oxygen ( $\mathrm{Cu}-\mathrm{O})$ bond expressed by the very low peak $466.7 \mathrm{~cm}^{-1}$ and $\mathrm{Cu}-\mathrm{H}_{2} \mathrm{O}$ bond is represented by the peak $644.2 \mathrm{~cm}^{-1}$. These values are in agreement with the results of previous research ${ }^{9}$.

\section{Effect of changing reaction factors on compound formation}

To study Effect of changing reaction factors on compound formation, we performed a series of five experiments, modifying each time one of the conditions associated with the experimental factors. We obtained results as mentioned in Table 4.

Table 4 : Conditions and experimental results for sample preparation

\begin{tabular}{|c|c|c|c|c|c|c|c|}
\hline $\mathrm{N}^{\circ}$ & $\mathrm{n}(\mathrm{mol})$ & $\mathrm{V}(\mathrm{ml})$ & $\mathrm{pH}$ & $\mathrm{T}\left({ }^{\circ} \mathrm{C}\right)$ & $t$ (day) & $\mathrm{m}(\mathrm{g})$ & Product \\
\hline 1 & $\begin{array}{c}\mathrm{nCu}\left(\mathrm{NO}_{3}\right) 3 \cdot \mathrm{H}_{2} \mathrm{O}=10^{-3} \\
\mathrm{nH}_{2} \mathrm{C}_{4} \mathrm{O}_{4}=5 \cdot 10^{-4}\end{array}$ & $\begin{array}{l}\mathrm{V}_{\mathrm{H} 2 \mathrm{O}}=15 \\
\mathrm{~V}_{\mathrm{H} 2 \mathrm{O}}=15\end{array}$ & 0,87 & T.A & 1 day & 0,0799 & \\
\hline 2 & $\begin{array}{c}\mathrm{nCu}\left(\mathrm{NO}_{3}\right) 3 \cdot \mathrm{H}_{2} \mathrm{O}=10^{-3} \\
\mathrm{nH}_{2} \mathrm{C}_{4} \mathrm{O}_{4}=5 \cdot 10^{-4}\end{array}$ & $\begin{array}{l}V_{\text {ethanol }}=15 \\
V_{\text {ethanol }}=15\end{array}$ & 0,87 & T.A & 4 day & 0,1039 & \\
\hline 3 & $\begin{array}{c}\mathrm{nCu}\left(\mathrm{NO}_{3}\right) 3 \cdot \mathrm{H}_{2} \mathrm{O}=10^{-3} \\
\mathrm{nH}_{2} \mathrm{C}_{4} \mathrm{O}_{4}=5.10^{-4} \\
\mathrm{nNaOH}=0.02\end{array}$ & $\begin{array}{l}\mathrm{V}_{\mathrm{H} 2 \mathrm{O}}=15 \\
\mathrm{VH}_{2 \mathrm{O}}=15\end{array}$ & 11 & T.A & 5 day & 0,154 & \\
\hline 4 & $\begin{array}{c}\mathrm{nCu}\left(\mathrm{NO}_{3}\right) 3 \cdot \mathrm{H}_{2} \mathrm{O}=10^{-3} \\
\mathrm{nH}_{2} \mathrm{C}_{4} \mathrm{O}_{4}=5 \cdot 10^{-4}\end{array}$ & $\begin{array}{l}\mathrm{VH}_{20}=7 \\
\mathrm{VH}_{20}=7\end{array}$ & 1,31 & $\begin{array}{c}80 \mathrm{C}^{\circ} \\
\text { For } 35 \mathrm{~min}\end{array}$ & 5 day & 0,1042 & \\
\hline 5 & $\begin{array}{c}\mathrm{nCu}\left(\mathrm{NO}_{3}\right) 3 \cdot \mathrm{H}_{2} \mathrm{O}=10^{-3} \\
\mathrm{nH}_{2} \mathrm{C}_{4} \mathrm{O}_{4}=5 \cdot 10^{-4}\end{array}$ & $\begin{array}{l}\mathrm{VH}_{2 \mathrm{O}}=15 \\
\mathrm{VH}_{2 \mathrm{O}}=15\end{array}$ & 1.5 & $\begin{array}{c}80 \mathrm{C}^{\circ} \\
\text { For17 min }\end{array}$ & 1 day & 0,0347 & \\
\hline
\end{tabular}

Most of the samples were prepared at room temperature. Table 4 results shows that the high temperature did not affect final product nature, whereas color of product change. It is noted that the interaction of copper nitrate and squaric acid in the presence of $\mathrm{NaOH}(\mathrm{pH}=11)$ increases the yield of the reaction relative to the other samples. Duration of the interactions was short and in all cases we obtained samples in powder form.

To determine modification effect of reaction factors on the experimental product of previous series of reactions, we recorded FTIR spectra of five remaining samples (Fig. 5) and compared them template spectrum. All spectra were almost identical in terms of spectrum but marked by significant displacements. However, we note that same group can lead to several types of vibrations and therefore to absorption at different frequencies and explains these different experimental conditions from one sample to another.

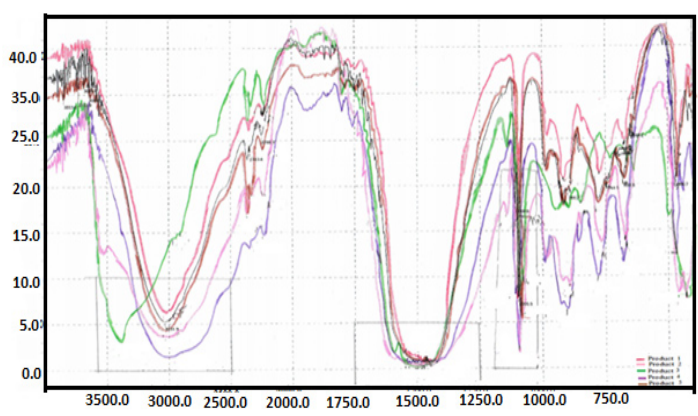

Fig. 5. FT-Infrared superposition depending on modified parameter of the reaction

The comparison of the IR spectra in the highest frequency, related to the $\mathrm{O}-\mathrm{H}$ indice elongation motions, does not show significant difference between the four crystalline forms with 
the exception of the sample noted product 3.The product 2 coded spectrum shows an increase in band width and density, indicating the presence of impurities in the sample and an increase in alcoholic $(\mathrm{OH})$ function, this can be justified by the nature of the solvent use (ethanol).

Raising the reaction temperature from ambient to $80^{\circ} \mathrm{C}$ does not affect the nature of the final product. The reaction time was short and we obtained the samples in powder form in all cases. With regard to the effect of $\mathrm{pH}$, the reaction carried out at $\mathrm{pH}=11.04$ represented by the spectra coded product 3 , the width of the band has been decreased with the position centered at about $3384.8 \mathrm{~cm}^{-1}$ and the emergence of a new band at $1125 \mathrm{~cm}^{-1}$. In the lower frequency region small energy differences could be observed, although the form of the bands is identical in exption for product 3 and 5 at $898.8 \mathrm{~cm}^{-1}$. In the domain (6444.66) $\mathrm{cm}^{-1}$ those band belonging to $\mathrm{Cu}-\mathrm{O}$.

\section{CONCLUSION}

In this research, we presented the synthesis, identification and study of the reactivity of a chemical compound of formula $\mathrm{CuC}_{4} \mathrm{O}_{4} \cdot 2 \mathrm{H}_{2} \mathrm{O}$ using physicochemical analysis techniques to determine its quantitative and qualitative composition and describe its crystalline structure. Using the X-ray diffraction technique, we have defined the vibrations of the functional group by infrared radiation, in order to be able to give a spectrum to the study of variation of the reaction parameters on the nature of the product.

We concluded similarity in the spectrum when we change the temperature concentration and time of the reaction so their general structure is similar. The modification of the $\mathrm{pH}$ and of the solvent leads to the increase of alcoholic function and the presence of impurities in the product.

\section{ACKNOWLEDGMENT}

This research was supported by the Algerian Ministry higher education and scientific research (Project PROFAS B). We thank the CRAPC center for helpful discussion, and the facility to use his experimental equipment.

\section{REFERENCES}

1. Frankenbach, G. M.; Beno, M. A.; Kini, A. M.; Williams, J. M.; Welp, U.; Thompson, J. E.; Inorg Chim Actu., 1992, 192, 195-200.

2. Robl, C.; Weiss.; Z. Naturforsch., 1986, 41, 1341-1345.

3. Boultif, A.; Louer, D.; J. Appl. Cryst., 2004, 37, 724-73.

4. Louer, D.; Louer, M.; J. Appl. Cryst., 1972, 5, 271-275.

5. James, T.; Reinprecht, J. G.; Miller, G.
C.; Vogel, M. S.; HADDAD,'H.; Inorganic Chemistry., 1980, 19, 374-385.

6. Bellamy, L. J.; Chapman and Hall., 1975,

7. Baglin, F.G.; Rose, C.B.; Spectrochim. Acta., 1970, 26, 2293.

8. Erer, H.; Yesilel, O.Z.; Büyükgüngör, O. Polyhedron., 2010, 29, 1163-1167.

9. Doreswamy, B. H.; Mahendra, M.; Sridhar, M. A.; Prasada, S. J.; Varughese, P. A.; George, J.; Varghese, G.; Materials Letters., 2005, 59, 1206-1213. 